\title{
Corrigendum
}

\section{There Can Be No Compromise: Institutional Inclusiveness, Fractionalization and Domestic Terrorism - CORRIGENDUM}

\author{
DENNIS M. FOSTER, ALEX BRAITHWAITE AND DAVID SOBEK
}

doi:10.1017/S0007123412000464, Published by Cambridge University Press, 10 October 2012.

Page 12, Table 1, Model 3: The regression coefficient and associated z-statistic for the interaction term "Majoritarian X ELF" should read as follows:

$$
-4.474 * *(-3.21)
$$

Page 12, Table 1, Model 4: The regression coefficient and associated z-statistic for the interaction term "Mean District Magnitude X ELF" should read as follows:

$$
0.075^{* *}(5.21)
$$

\section{REFERENCE}

Dennis M. Foster, Alex Braithwaite and David Sobek. There Can Be No Compromise: Institutional Inclusiveness, Fractionalization and Domestic Terrorism. Brit J Polit Sci. Published by Cambridge University Press, 10 October 2012. doi:10.1017/S0007123412000464. 